تعيين دوره بحر انى علفهاى هرز خيار گلخانهاى (Cucumis sativus L.) در گلخانه خاكى

\author{
حسين حمامى "، ليلا علىمرادى' و على سبهرى'
}

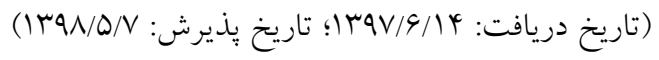

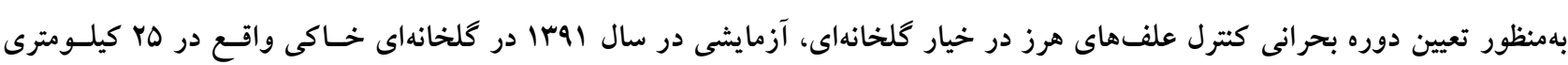

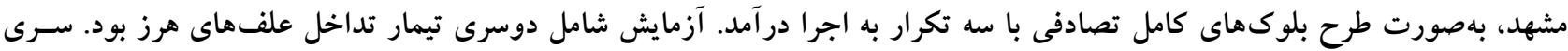

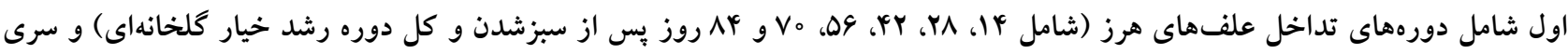

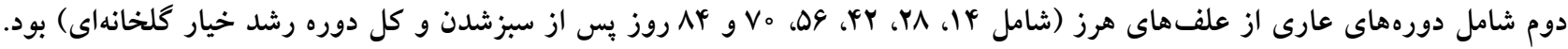

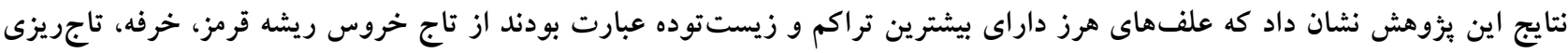

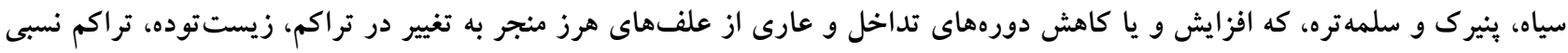

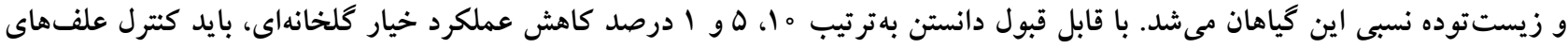

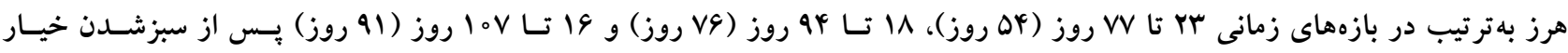

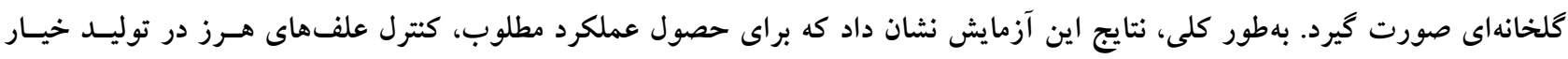
كلخانهاى ضرورى است.

وازههاى كليدى: تراكم، زيستتوده، كاهش عملكرد قابل قبول، علف هرز

كارخانهها، كنار جادهها، امتداد مسير راهآهن، محوطه فرودكاهها، مقدمه

ياركها، مخازن و منابع آب، نهرهاى آبيارى و مكانهـاى ديخـ

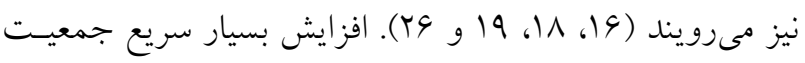

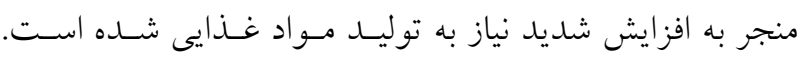

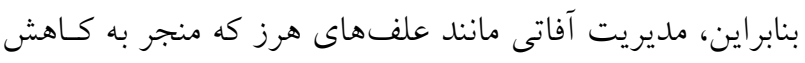

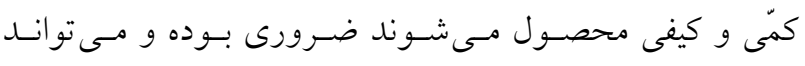

علفهاى هرز به كَياهان ناخواستهاى كفته مىشود كه بـرخلاف ميل انسان عمل مى كنند و در تداخل با فعاليتهاى انسان هستند

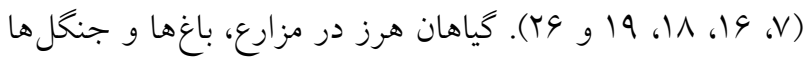
با كياه اصلى رقابت مى كنند و موجب كاهش كمّى و كيفى كيـاه

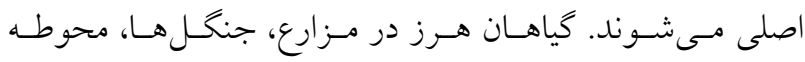

1. كروه زراعت و اصلاح نباتات، دانشكده كشاورزى، دانشكاه بيرجند

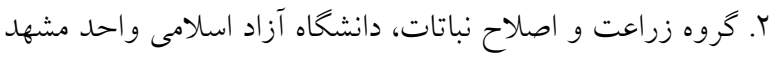

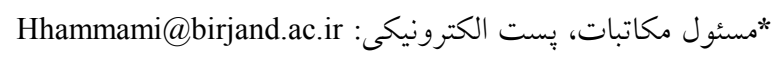


است. دوره بحرانى خسارت علفهرز شامل فاصله زمانى است كه اخر در طول آن دوره علفهاى هرز كتترل شوند از خسارت

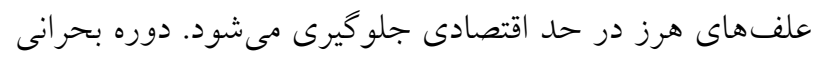

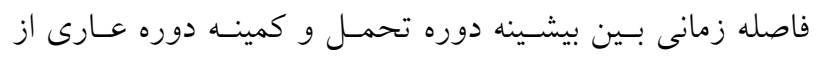

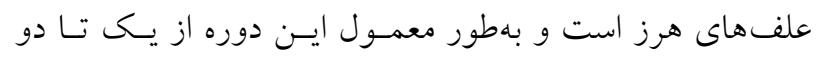

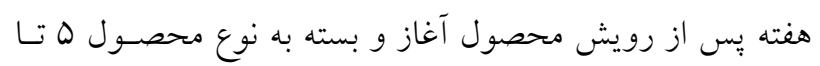

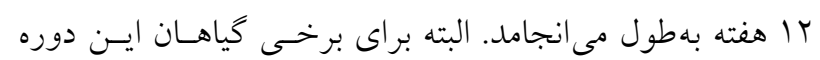

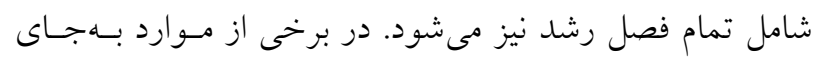

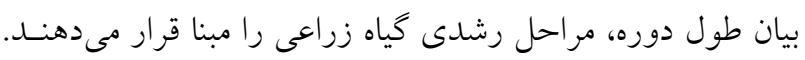

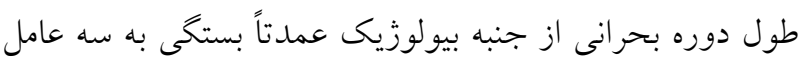

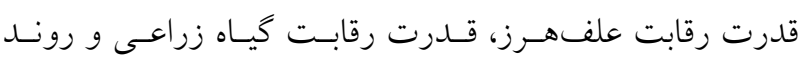

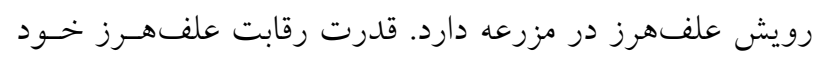

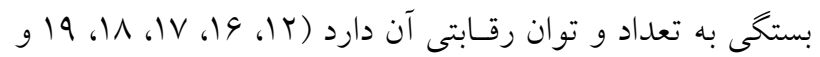

زمان آغاز دوره بحرانى هنخامى است كه در اثر ايجاد رقابت

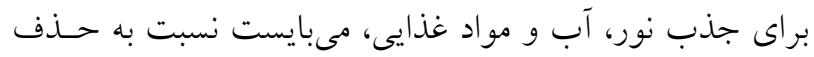
علف هاى هرز براى ممانعت از كاهش عملكرد اقدام كرد (11).

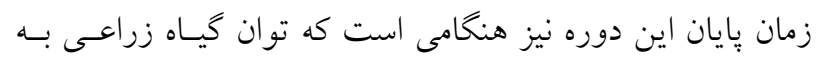

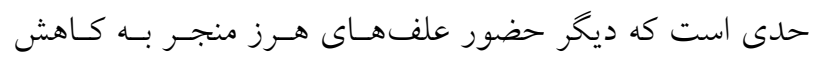

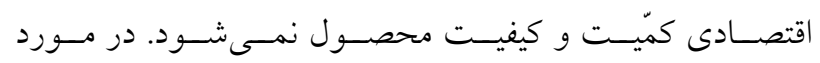
محصولات مختلف گزارشهاى متعددى كـه نشـاندهنـــه دوره

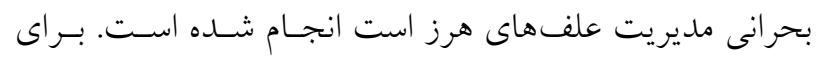

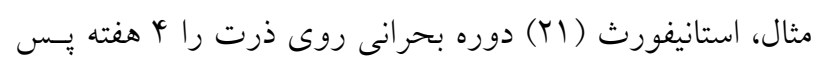

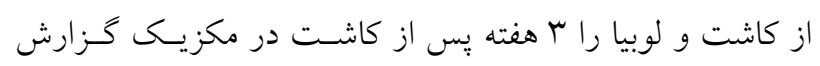

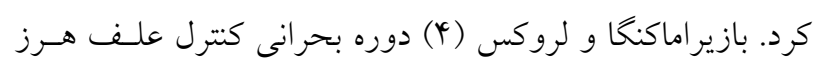

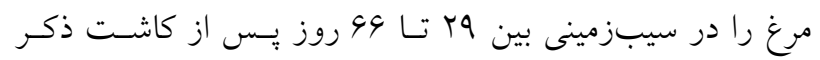

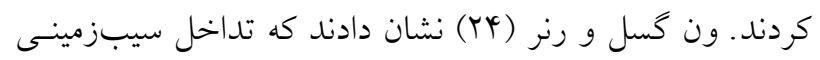

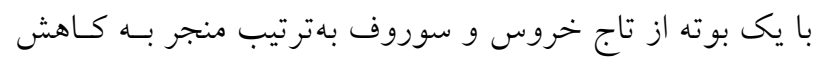

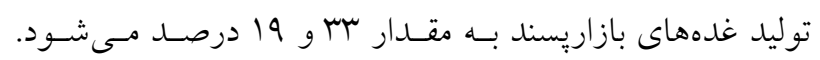

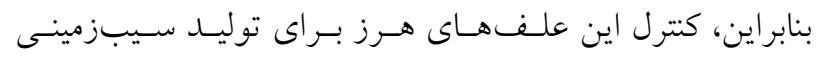

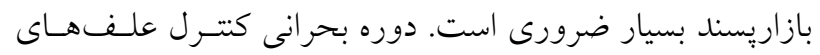

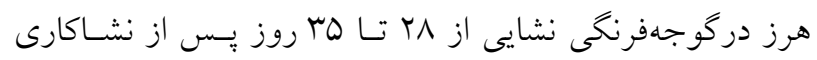

بهنعنوان يكى از مهم ترين راههاى رفع مشكل نياز به توليد مـواد

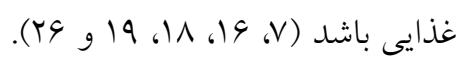

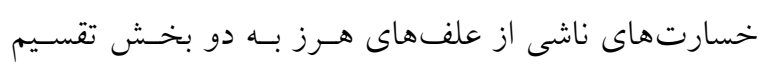

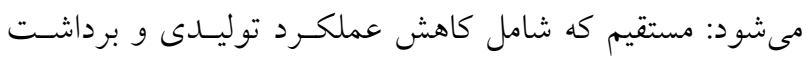

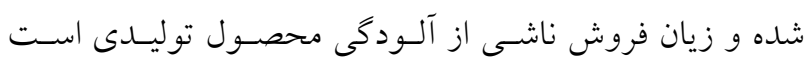

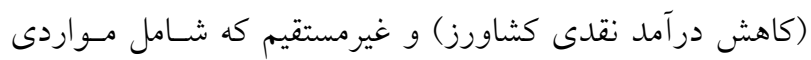

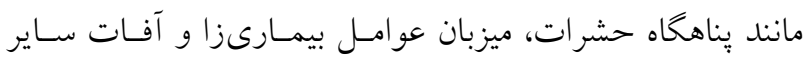
محصولات و كياهان مطلوب مىشود (9 1، 11، 19 و و Y).

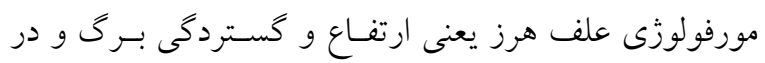
نهايت يوششى كه بركهاى علف هرز روى سطح خاك مى تو انند

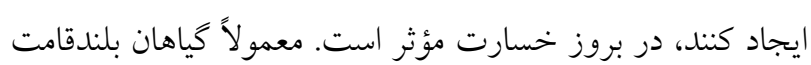

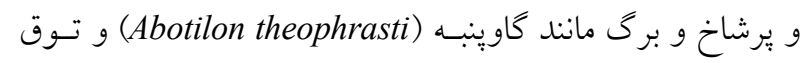
علاوه بر مواد غـذايى، بـراى دريافـت (Xanthium strumarium)

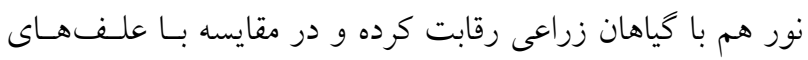

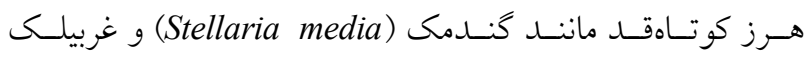
خسارت بيشترى وارد مىسـازند. البتـه برخسى از و عربيل (Lamium spp)

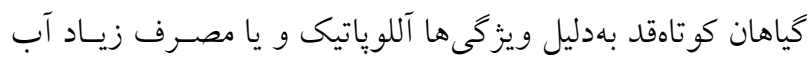

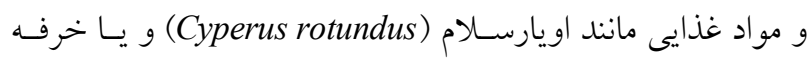
خسارت بسيار زيادى را به كياهان كشت و شده وارد مىسازند (r) (I).

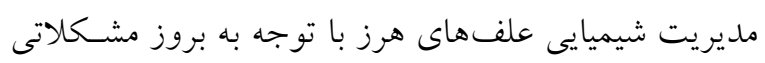

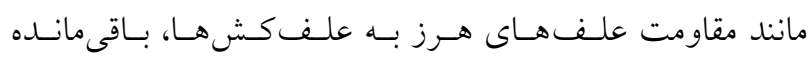

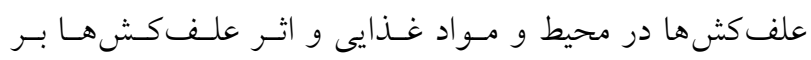

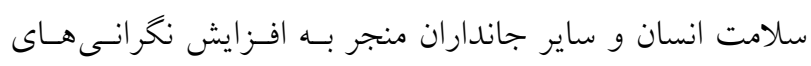

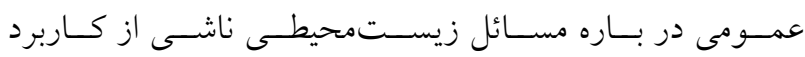

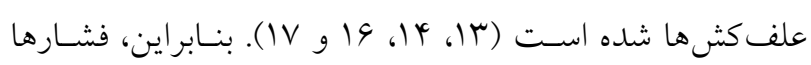

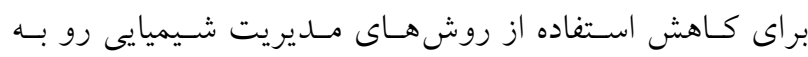

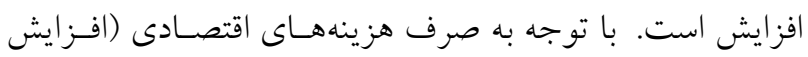

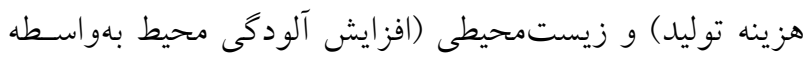

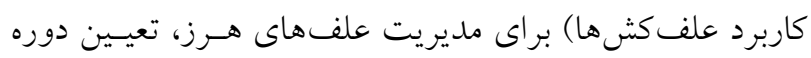

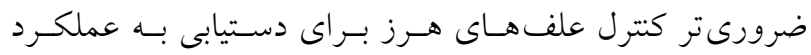

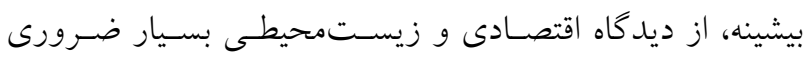


واقع در شهرستان طرقبه شانديز روسـتاى سر آسـياب (خراسـان

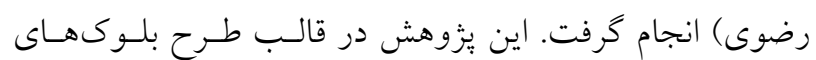

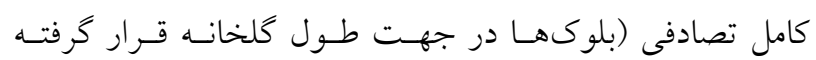

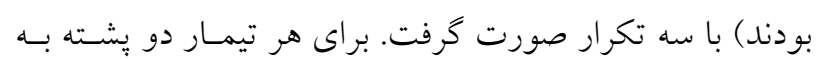

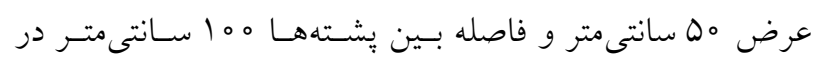

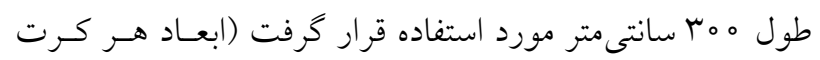

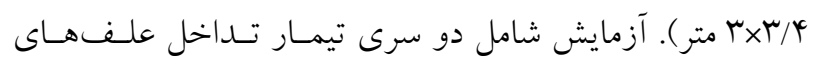

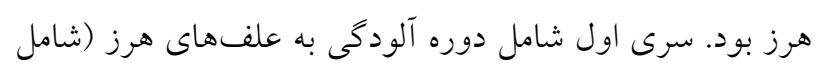

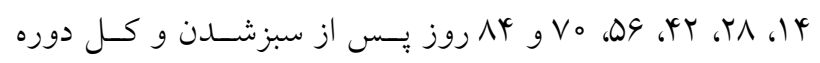

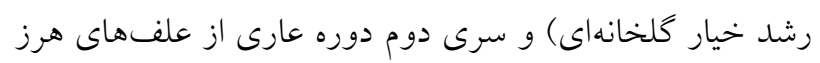

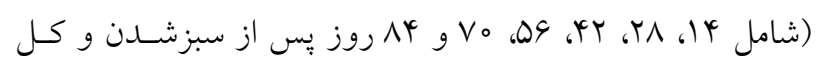
دوره رشد خيار كلخانهاى) بود.

مشخصات كلخانه

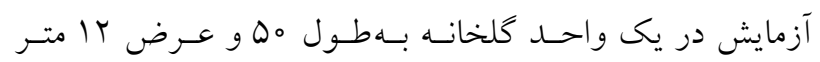

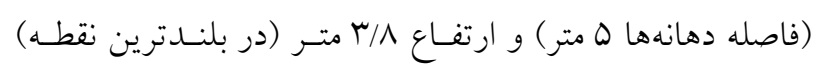

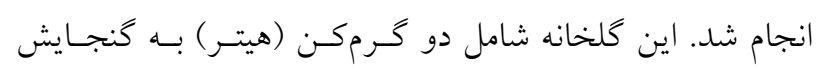

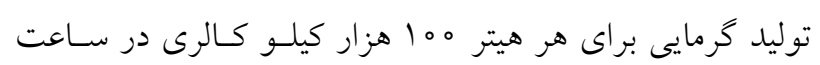
بود. سوخت اين واحلد كرمايى از نفـت كـاز (كازوئيسل) تــأمين

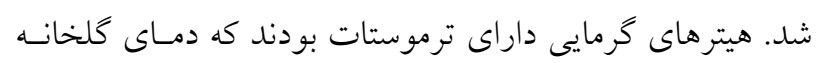
را بهصورت اتومات در روز ها درجه سلسيوس و در شـب درمائ 19 درجه سلسيوس تنظيم مىكردند. سيستم تهويه كلخانه داراى دو

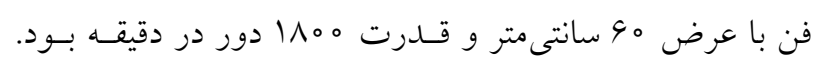

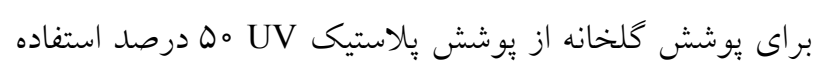

\section{عمليات آمادهسازى و كشت}

يَيش از كشت، از نقاط مختلف كُلخانه نمونه مركب خاك تهيـهـ

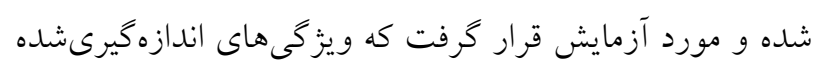
در جدول (1) نشان داده شده است.

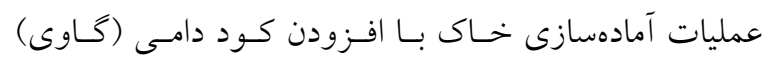

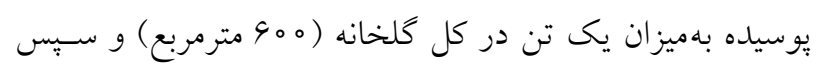

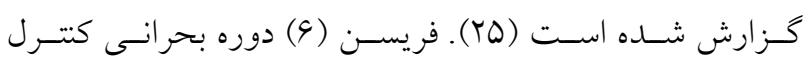

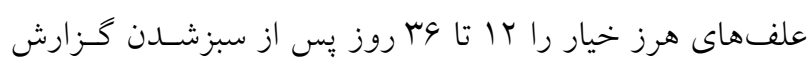

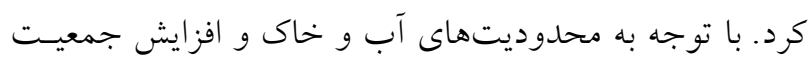

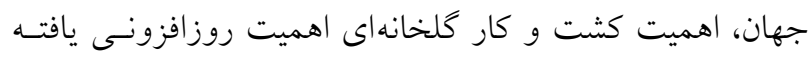

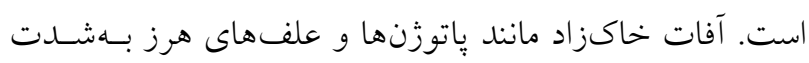
بر كمّيت و كيفيت محصولات توليدى اثر منفى مى كذارنــ (م).

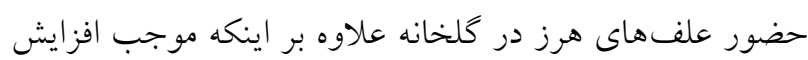
رقابت براى آب، نور و مواد غذايى مى شوده، باعث افزايش آفات

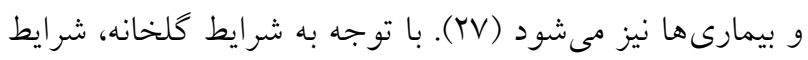

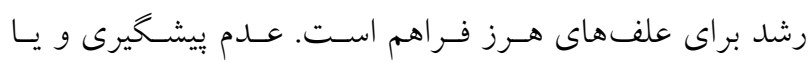

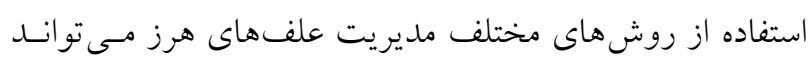

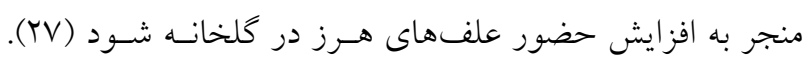

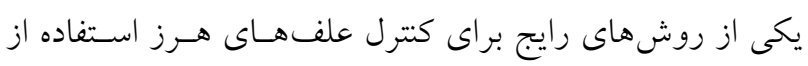

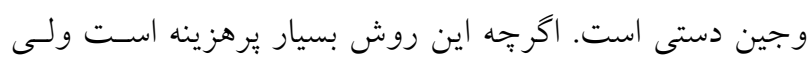

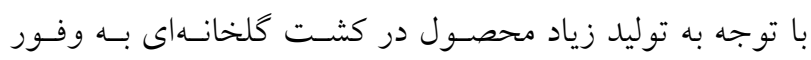

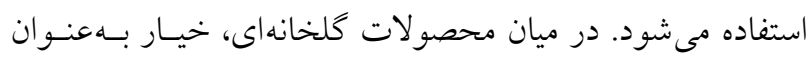

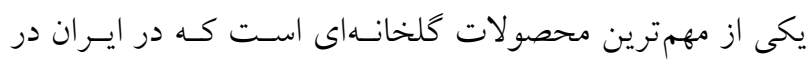

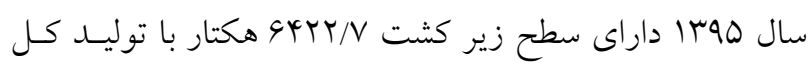

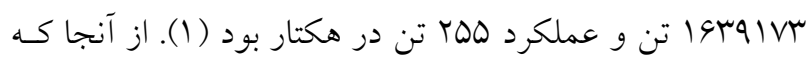

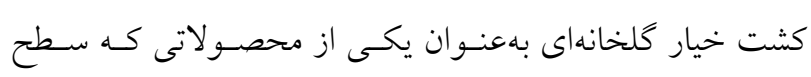

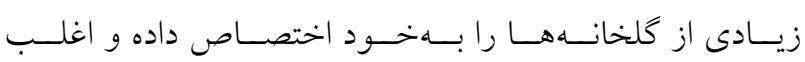

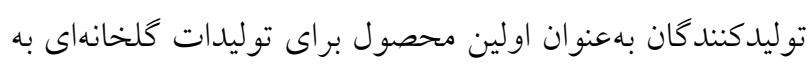

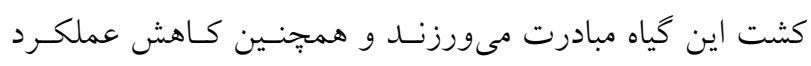

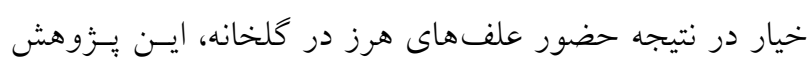

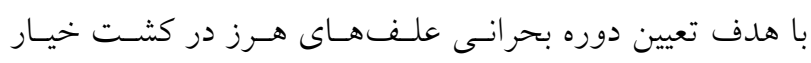

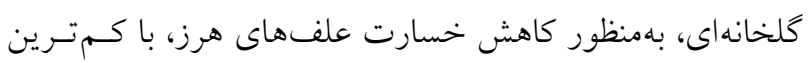

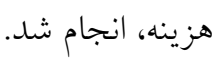

مواد و روشها مكان انجام آزمايش

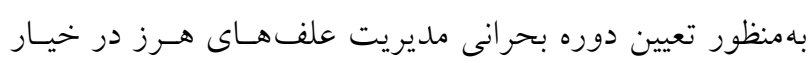

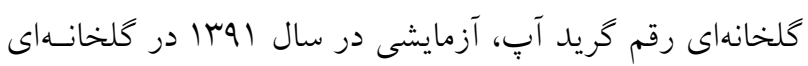


جدول ا. ويزّى هاى فيزيكى و شيميايى خاك مورد استفاده براى انجام آزمايش

\begin{tabular}{|c|c|c|c|c|c|c|c|}
\hline $\begin{array}{c}\mathrm{K} \\
(\mathrm{ppm})\end{array}$ & $\begin{array}{c}\mathrm{P} \\
(\mathrm{mg} / \mathrm{kg})\end{array}$ & $\begin{array}{l}\mathrm{N} \\
(\%)\end{array}$ & $\begin{array}{c}\mathrm{EC} \\
(\mathrm{dS} / \mathrm{m})\end{array}$ & $\mathrm{pH}$ & رس & سيلت & شن \\
\hline MET & 99 & $0 / 9$ & $r / \Lambda$ & $V / l$ & ry & r^ & ऍ \\
\hline
\end{tabular}

و يك روز بـ از كاشت، اولين ميوههـا روى بوتسههـا مشـاهده شدند. پنجاه و دو روز يس از كاشت، بيمارى سـفيدى سـطحى روى بوتهها مشاهده شد. بههمين خاطر، با سـم دينوكـاربّ بـر

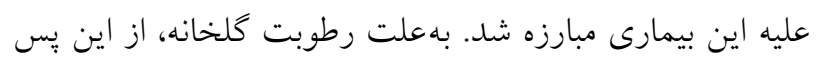

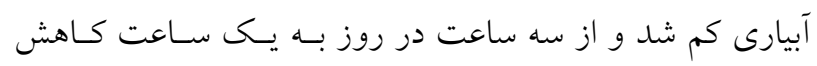
داده شد. همجنين، آبيارى با فواصل دو روز در ميان انجام شـد. در هه روز پس از كاشت، اولين سرى برداشت ميوه آغاز شد و خيارهاى برداشت شده براى هر تيمار بهصسورت مجـزا تـوزين

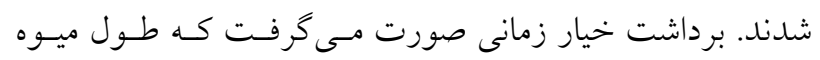

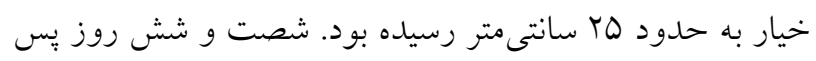
از كاشت، با مشاهده بيمارى سفيدى سـطحى مبـارزه بـا قـارج

$$
\text { كش تاراتان صورت گرفت. }
$$

\section{اندازهگيرى صفات و تجزيه تحليل دادهها} در اين مطالعه، صفت هاى اندازه گيرىشده شامل نـوع، تـــــم و وزن خشى كونههاى مختلف علفهاى هرز و عملكـــ نهـايى خيار در بوتـهـ بودنـــ. بــراى تجزيـهـ و تحليـل دادههــا از روش وايـازى غيرخطى (Nonlinear regression) و توابـع خـاميرتز (Gompertz equation) سY) به كمك نرمافزار 9.1 SAS استفاده شد. براى رسم نمودارها نيز از نرم|فزارهاى Excel و 11 Sigma Plot استفاده شد.

\section{نتايج و بحث} نتايج آزمايش نشان داد كه كونـههـاى غالـب علـفـهـاى هـرز

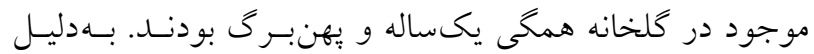
توسعه سريع سطح برى خيار، سـايهانـدازى سـريع و همجنــين شرايط كلخانه، گونههاى باريكبرى كمترى در كلخانه مشـاهده
شخم انجام شد. يس از شخمم عمليات خاكورزى ثانويه توسط كولتيواتور انجام شده و خاى تسـطيح شـــ. بـراى آمـادهسـازى خاك، ابتدا يشتههايى بهعرض مه سانتى متر در نظر گرفته شـد.

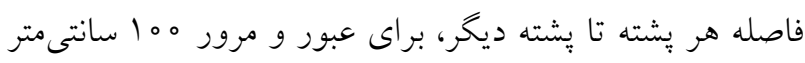

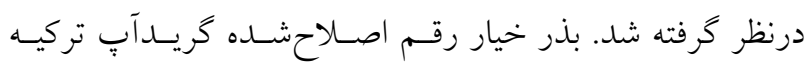
(رقمى :بر محصول با توليد ميوه خيار سبز بر رنخ و قلمى) كـه بهمدت ب M ساعت در حولهاى نمكرده بهمنظور تسهيل جوانهزنى و استقرار قرار گرفته بود روى هر يشته در دو رديف كشت شد.

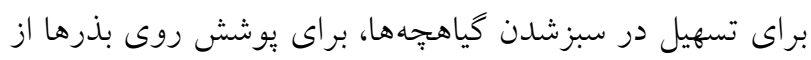
مخلوط كوكوييت و برليت بهنسبت مساوى استفاده شد. كاشـت بذرهاى خيار در اول شـهريورماه اوس| انجـام شـــ از سيستم آبيارى قطرهاى بهمنظور آبيـارى اسـتفاده شـد. يسـ از كاشـت، بهمنظور جلو گيرى از بوتهميرى، در آبيارى اول از محلول قـارج كش كايتان بهنسبت سه در هزار استفاده شـد. در فاصـله زمـانى بين كاشت و سبزشدن بذرهاى كاشتهشده، دماى كلخانه بين الى هب درجه سلسيوس تنظيم شد. يس از هشـت روز از رشـد

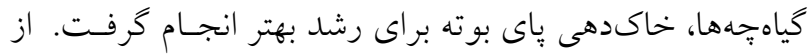
روز دوازدهم، نخ بستن يِى بوتههاى خيار آغـاز شـــ و از ايسن

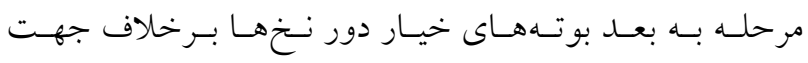

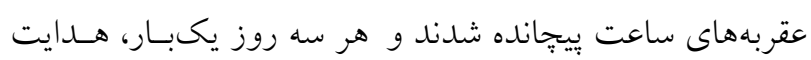
بوتهها دور نخها ادامه داده شد. در روزهاى يانزدهم، نشانههـاى آفت كنه بر بوتهها مشاهده شد كه با سـم نيسـرون سمياشسى و

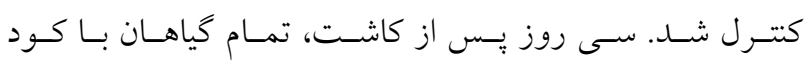
سكوسترين آهن تغذيه شدند. بهعلـت سـرماى شـبانه، سيسـتم كرمايى در روز سىام راهاندازى شد. سيستم بهصـورت اتومـات دماى شبانه را روى ^| درجـهـ سلسـيوس نخـهـ داشـت. در روز سى و دوم، اولين كل ها روى بوتههاى خيار مشاهده شد. جهـل 
جدول Y. مشخصههاى علفهاى هرز مشاهدهده در تيمارهاى آزمايشى

\begin{tabular}{|c|c|c|c|c|c|}
\hline مسير فتوسنتزى & 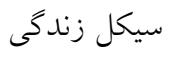 & مورفولوزى برى & خانو اده كياهى & 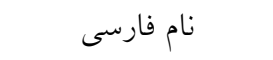 & ن ام علمى \\
\hline $\mathrm{C}_{4}$ & يكساله & ئين برى & Amarantaceae & تاجخروس ريشه قرمز & Amaranthus retroflexus \\
\hline $\mathrm{C}_{3}$ & يكساله & يهن برى & Malvaceae & ينيرك & Malva neglecta \\
\hline $\mathrm{C}_{3}$ & يكساله & يهن برى & Solanaceae & ت ت تاجريزى & Solanum nigrum \\
\hline CAM & يكساله & بيهن برى & Portulacaceae & خرفه & Portulaca oleracea \\
\hline $\mathrm{C}_{3}$ & يكساله & بهن برى & Chenopodiaceae & سلمه تره & Chenopodium album \\
\hline
\end{tabular}

افزايش دوره تداخل علفهاى هرز تا ه لروز بـس از سـبز

شدن خيار منجر به افزايش تراكم علفهاى هرز شد (شـكل 1-

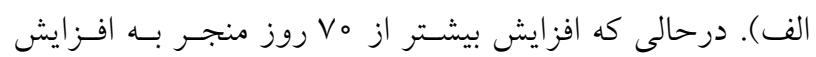
تراكم نشد. بهنظر مىرسد كه عامل اصلى افزايش رقابـت درون و بين كونهاى علفهاى هرز بوده كه بر اساس اصل طرد رقابتى منجر به حذف تعدادى از علفهاى هرز ضعيفتـر، كـه ديرتـر سبز شده و رشد كمترى داشـتهانـد، شـده اسـت (1) (1). افـزايش دوره تداخل علف هاى هرز منجر به تغيير تراكم نسبى هر گونـه علف هرز شد. بهطورى كه گونههايى كه تراكم كمى داشته و يـا حضور نداشتند، نمود بيشترى يافتــد (شـكل ا-ب). بنـابراين، افزايش تنوع كيـاهى علـفهـاى هـرز در نتيجـه افـزايش دوره تداخل علفهاى هرز با خيار مشاهده شد. افزايش دوره عارى از علف هاى هرز منجر به كاهش تـراكم علف هاى هـرز شـــ (شـكل r- الـفـ). بيشـترين ميـزان تـراكم علـــهــاى هـرز در تيمارهــاى داراى كمتـرين دوره عـارى از علفهاى هرز مشاهده شد. بهدليل عدم رقابت و شرايط مناسب در ابتداى فصل رشد، تعداد بسيار زيادى از بذرهاى علـفهـاى هرز جوانه زده و سبز شدند. بنابراين، كنتـرل مناسـب در اوايـل فصل رشد خيار كلخانهاى مسى توانـد منجــر بـه كـاهش تــراكم

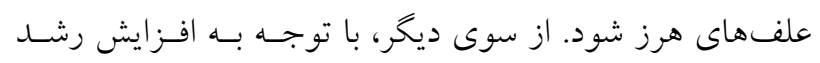

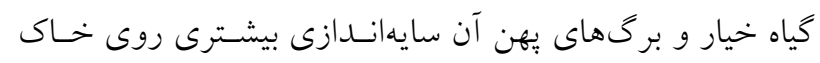

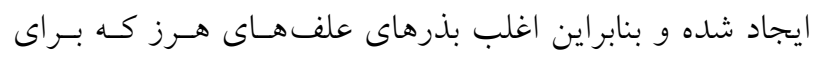

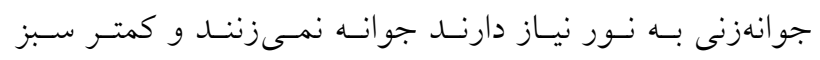
مىشوند. شكل (Y- الف) نشان مىدهد كـه در صـورت كنتـرل علف هاى هرز تا وها روز يس از سبزشدن خيار منجر به كـاهش
شدند. از طرف ديخر، بـهدليـل كشـت حسداقل دو بـار در سـال محصولات كلخانهاى در اين گلخانه و انجام شـخم حـداقل دو بار در سـال، علـفهــاى هـرز جنـدسـاله در تمـام طـول انجـام آزمايش مشاهده نشدند. مشخصههاى گونههاى غالب علف هرز در جدول (Y) نشان داده شده است. گونههاى علف هرز موجود در مزرعه و يا كلخانه بر طول دوره بحرانى مديريت علفهـاى هرز و همجينين زمان شروع مديريت علفهاى هرز مؤثر اسـت.

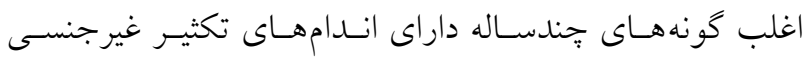

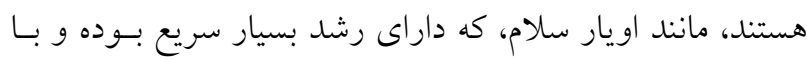

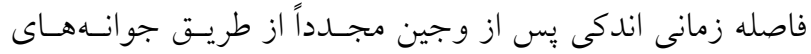

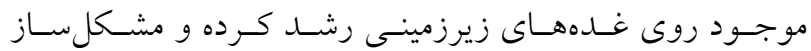
مى شوند.

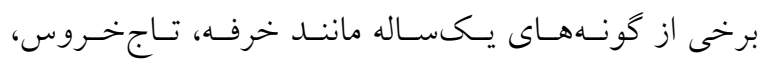
تاجريزى و سلمهتره نيز بهدليـل توليــ بـــر بسـيار زيـاد داراى ذخيره زيادى در بانك بذر خاك بوده و بنابراين سبزشدن مداوم

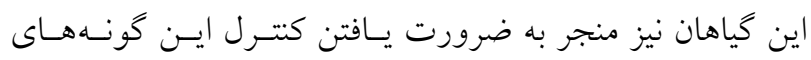
يكساله براى حصول عملكرد مطلوب مى شـود. بـهدليـل تـأمين

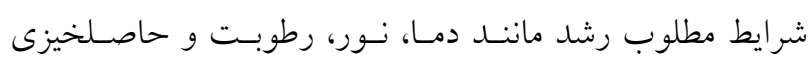
خاى در شرايط كلخانه، علفهاى هرز كه گياهانى فرصتطلب

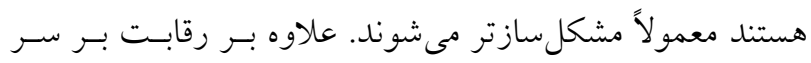

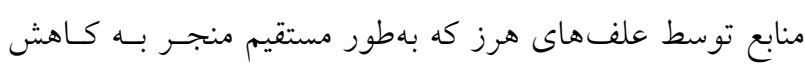
عملكرد مى شود، علف هاى هرز بهدليل اينكه ميزبان بسـيارى از آفات و بيمارىها هستند منجر به شيوع آفـات و بيمـارىهـا در كلخانه شده كه در نهايت منجر بـه كـاهش عملكــرد مسىشـوند .$(19,11,19,10)$ 

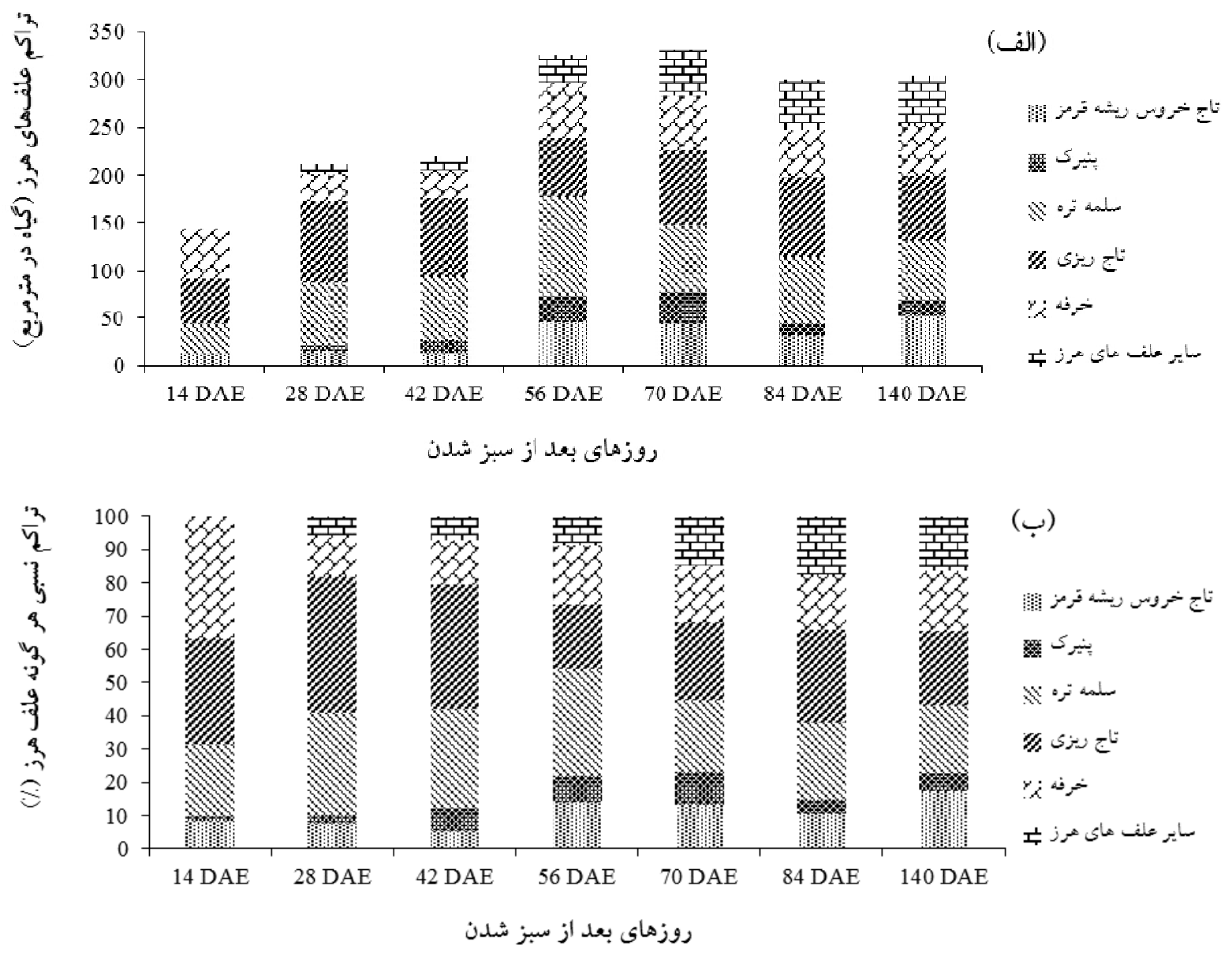

شكل ا. الف) تراكم علفهاى هرز و ب) تراكم نسبى هر گونه در دورههاى تداخل با علفهاى هرز

زيستتوده توليدى علفهاى هرز در واحد سـطح شـده كـه در

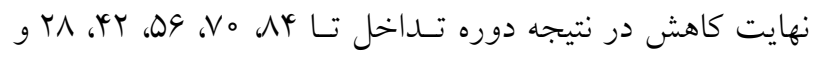

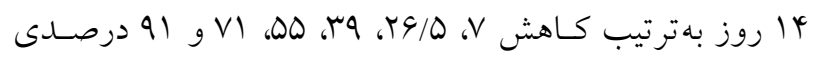
زيست توده علفهاى هرز را نشان داد (شكل ب- الـف). عـلاوه بر اين، سهم عملده افزايش زيست توده علف هاى هرز مربوط بـهـ

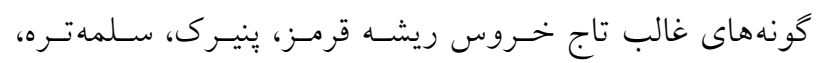

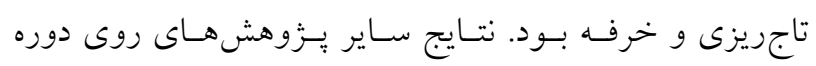
بحرانى كتترل علف هاى هرز نيز نشاندهنده افزايش زيستتوده توليدى توسط علفهاى هرز با افزايش دوره تداخل اسـت كـه البته ميزان افزايش زيست نوع و تراكم علفهاى هرز و همجنين نوع محصول كشتشــده

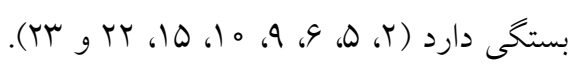

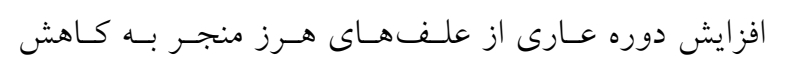

حدود 1ه درصدى تراكم علف هاى هرز مىشود؛ يعنى تراكم از

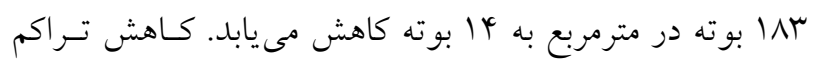
علف هاى هرز در تيمارهاى مختلف داراى دورههـاى عـارى از علفهاى هرز در ساير تحقيقات نيز بيان شـده اسـت ( (r، ه، و، 9 تراكم نسبى كونههاى مختلف علف هرز نيز بـهدليـل بِاسـخ متفاوت به تغييرات محيط كلخانه مانند نور (بهدليل سايهانـدازى خيار) منجر به واكنش متفاوت كياهان هرز شده است. بهطـورى كه با افزايش دوره عارى از علفهاى هرز و رشد بيشـتر خيـار

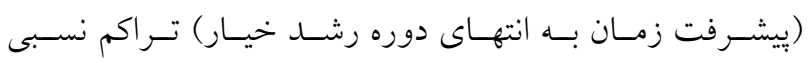
كونه هايى كه حساسيت كمترى به نور براى جوانسهزنسى داشـته، مانند خرفه، افزايش يافته است (شكل r- ب) (19 و Y (19). كـاهش دوره تـداخل علـفنهـاى هـرز منجــر بــه كـاهش 


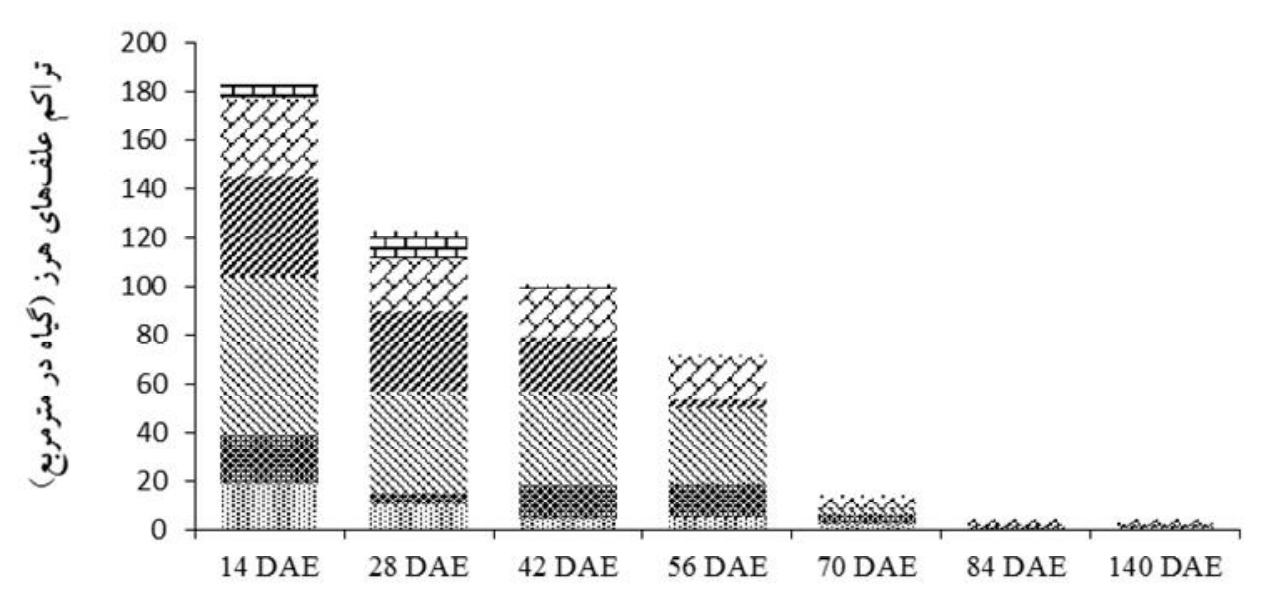

ساير علف عاى هرز

Y خرف

تاج بزى

سلمه تر:

بنيرك

تاج خروس ريشه قرمز

روزهاى بعد از سبز شدن

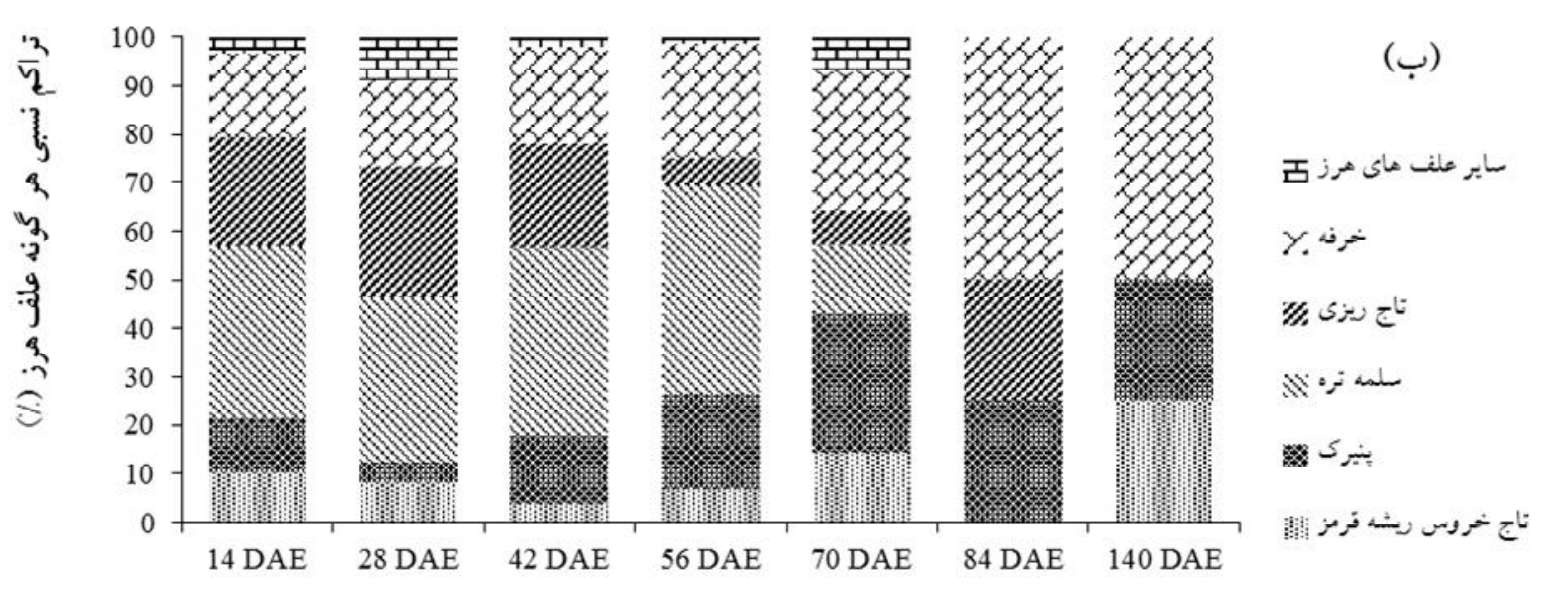

$$
\text { روزهاى بعد از سبز شدن }
$$

شكل r. الف) تراكم علفهاى هرز و ب) تراكم نسبى هر گونه در دورههاى عارى از علفهاى هرز

هاى هرز بهترتيب در تيمارهاى تداخل و عارى از علف هرز در

$$
\text { كشت خيار توسط فريسن (9) نيز خزارش شده است. }
$$

منحنى هاى حاصل از برازش دادهها به معـادلات كَاميرتز و

لجستيك نشان مىدهد كه افزايش دوره حضور علفهاى هرز و

دوره عارى از علفهاى هرز بهترتيب منجر به كاهش و افزايش

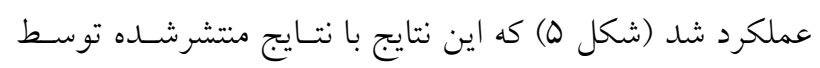

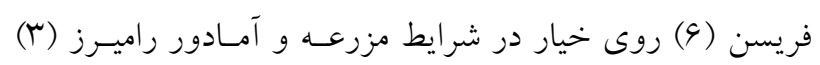
روى فلفل در شرايط مزرعه همخوانى دارد.

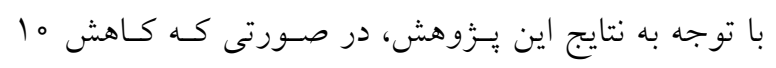

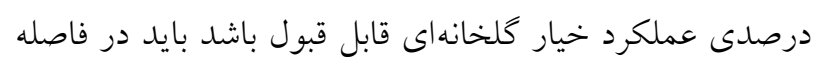
زمانى بين سب روز تا VV روز يس از سبز شدن خيار كلخانسهاى
زيست توده توليدى توسط علف هاى هرز شده است (شـكل r ب-

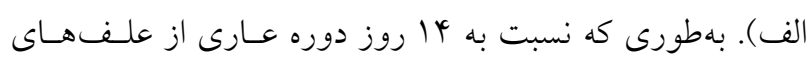

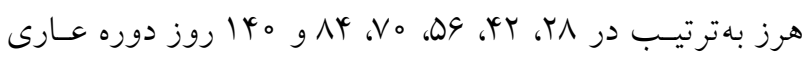

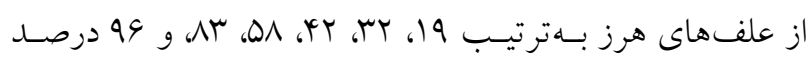
كاهش زيست توده علفهاى هرز مشاهده شد. سهم زيست توده علف هاى هرز مختلف نيـز بـا تغييـر دوره عارى از علفهاى هرز تغيير كرده بهطورى كه با افزيش ايش دوره عارى از علف هاى هرز سهم ساير كونههاى علفـهــرز بـهدليـل

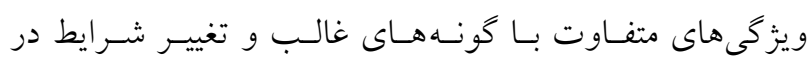
تيمارهاى نهايى دورههاى عارى از علفهاى هرز افزايش يافتسه

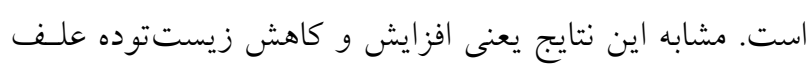



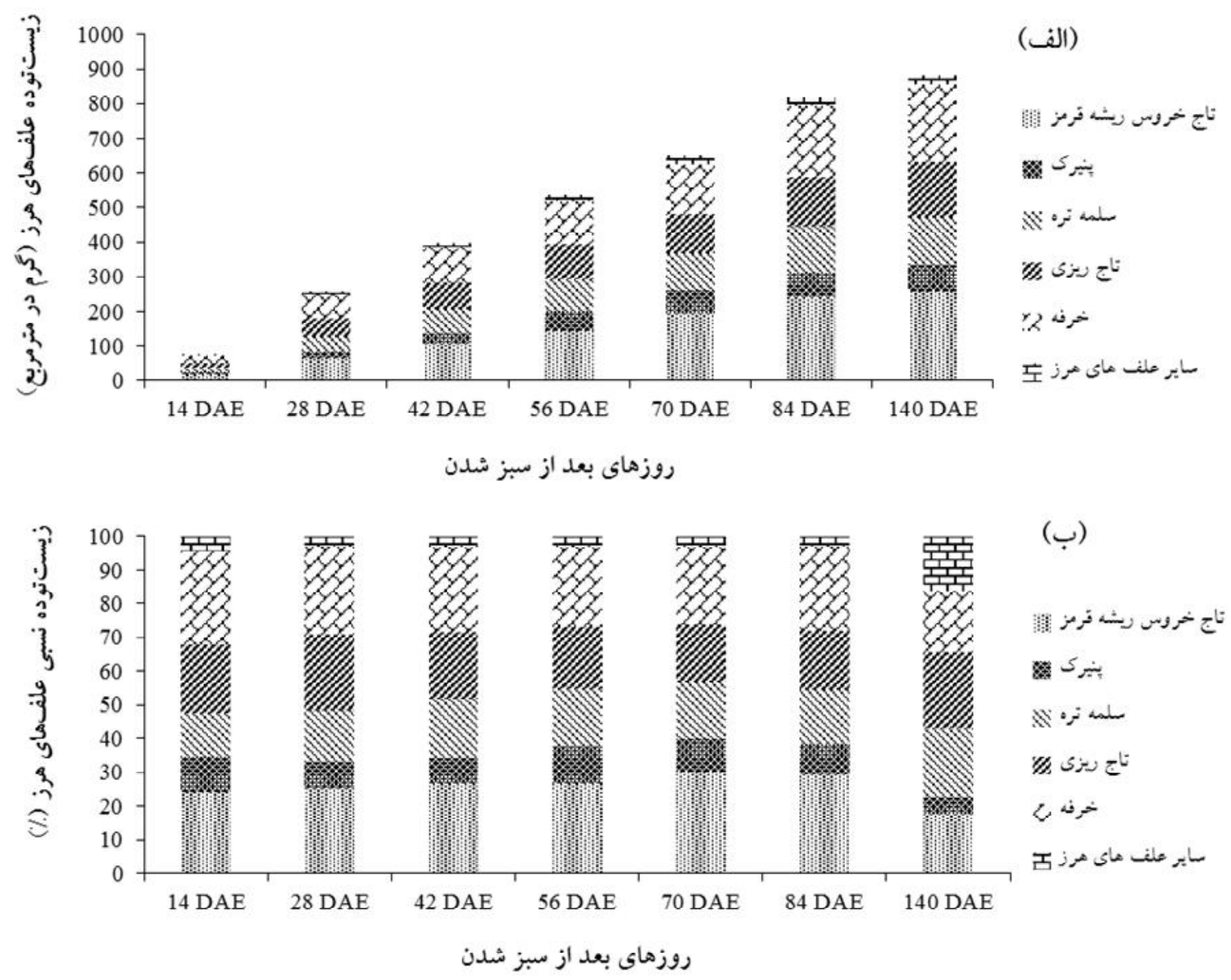

شكل r. الف) زيستوده علفهاى هرز و ب) تراكم نسبى هر گونه در دورههاى تداخل با علفهاى هرز

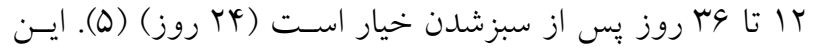

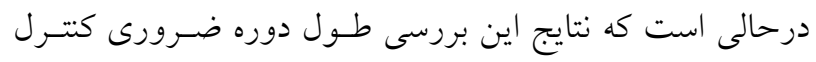

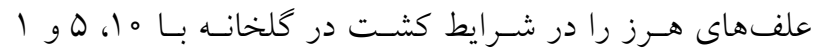

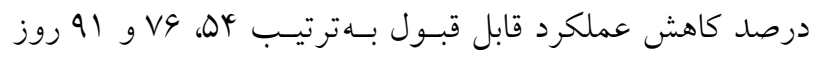

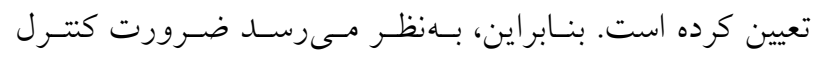

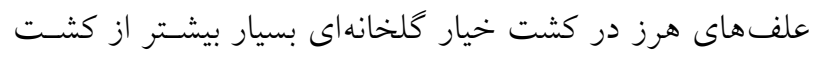
در شرايط مزرعه است.

\section{نتيجه گيرى}

نتايج اين بُزوهش نشان داد كه تمامى علف هاى هرز مشكل ساز

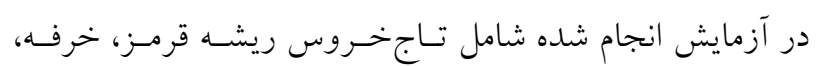

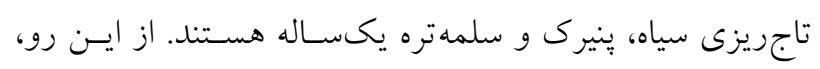

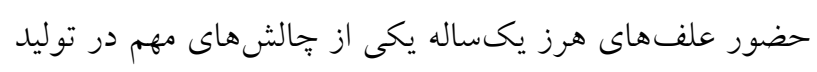

اقدام به كنترل و مديريت علف هاى هـرز كـرد (طـول دوره OF

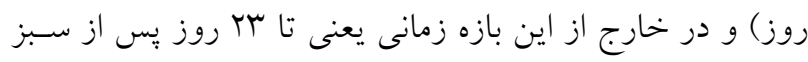

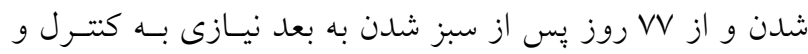

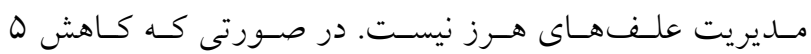
درصدى عملكرد خيار كلخانهاى قابل قبول باشد بايد در فاصله

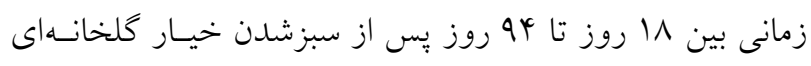

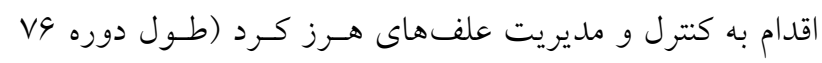

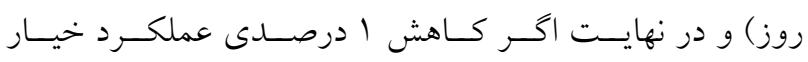

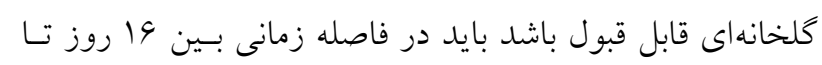

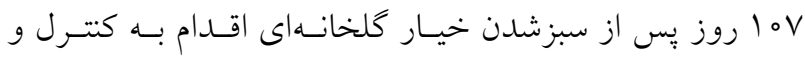

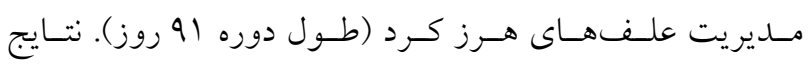
منتشرشده توسط برخى دانشمندان در شرايط مزرعه نشـان داده كه دوره بحرانى كنترل و مديريت علف هاى هرز در خيـار بـين درسين 


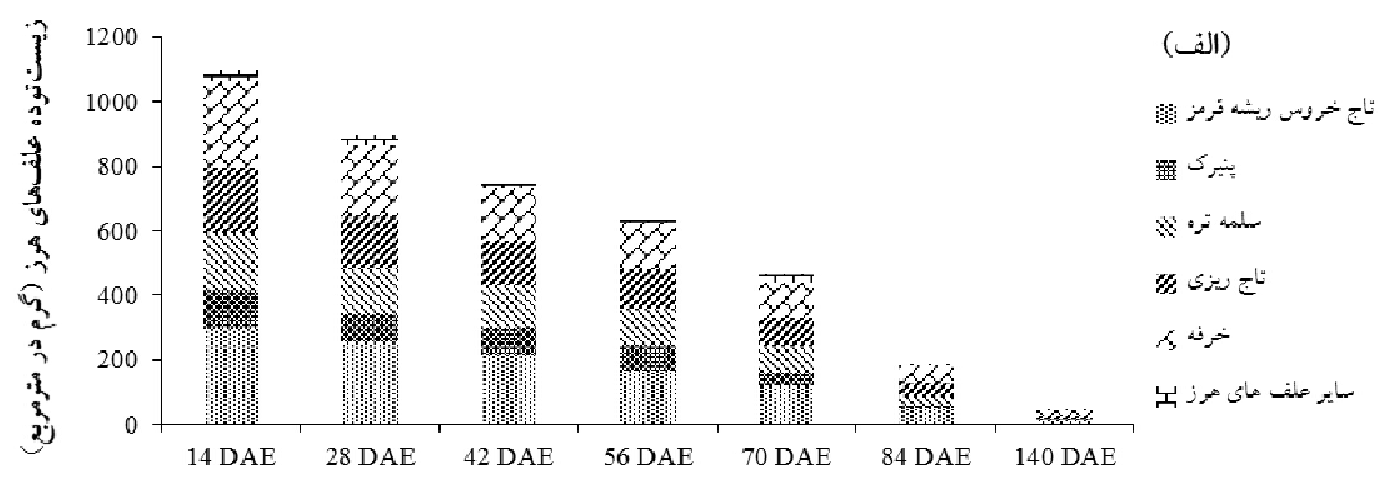

$$
\text { روزهاى بعد از سبز شدن }
$$

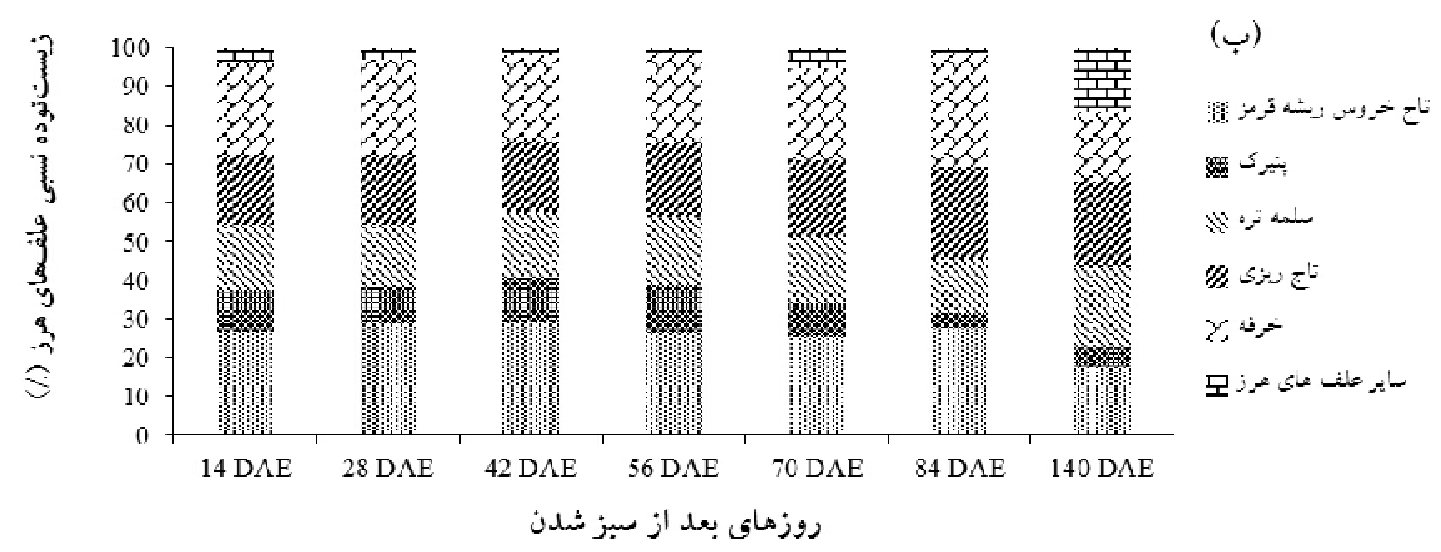

شكل f. الف) زيست توده علفهاى هرز و ب) تراكم نسبى هر گونه در دورههاى عارى از علفهاى هرز

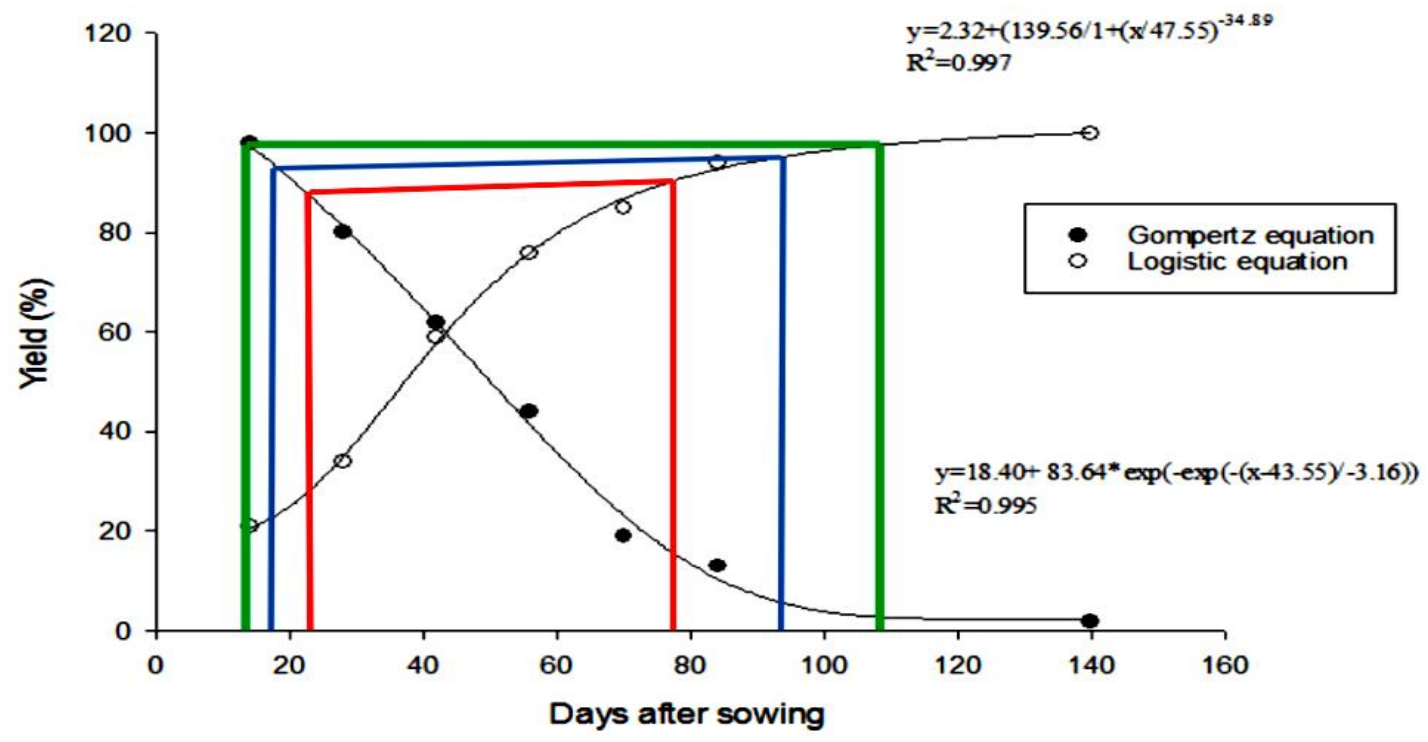

شكل ه. اثر افزايش دورههاى تداخل علفهاى هرز (O) و عارى از علفهاى هرز (•) بر عملكرد خيار گلخانهاى در شرايط •ا (خطوط قرمز)، ه (خطوط آبى) و ا(خطوط سبز) درصد كاهش عملكرد قابل قبول؛ معادله بالايى نشاندهنده واكنش عملكرد خيار كلخانهاى تحت تأثير دورههاى تداخل علفهاى هرز بر اساس مدل لجستيك است و معادله يايينى نشاندهنده واكنش عملكرد خيار گلخانهاى تحت تأثير دورههاى عارى از علفهاى هرز بر اساس مدل گامبرتز است (رنخى در نسخه الكترونيكى). 


$$
\begin{aligned}
& \text { خيار كلخانهاى است. افزايش و يا كـاهش دورههـاى تــاخل و ادرصد كاهش عملكرد خيار كلخانهاى بايد كنترل علـفهـاى }
\end{aligned}
$$

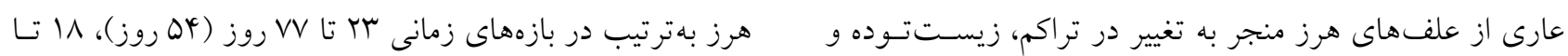

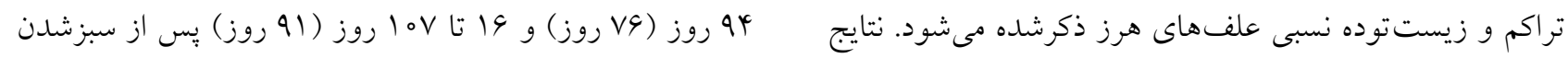

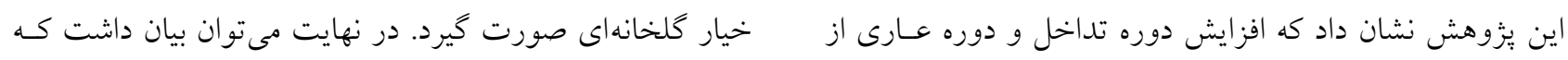

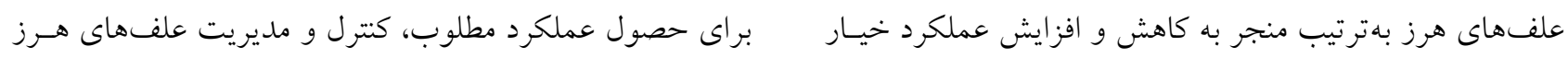

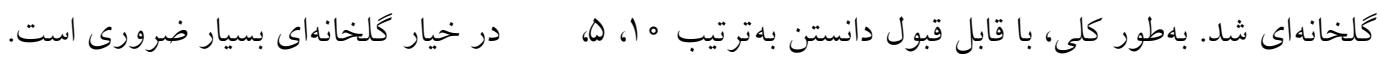

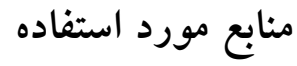

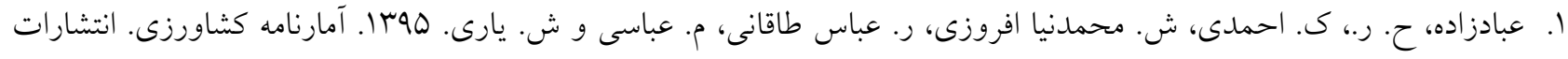

$$
\begin{aligned}
& \text { وزارت جهاد كشاورزى، معاونت برنامهريزى و اقتصادى، مركز فناورى اطلاعات و و ارتباطات. }
\end{aligned}
$$

2. Ahmadvand, G., F. Mondani and F. Golzardi. 2009. Effect of crop plant density on critical period of weed competition in potato. Sci. Hort. 121(3): 249-254.

3. Amador-Ramirez, M.D. 2002. Critical period of weed control in transplanted chilli pepper. Weed Res. 42: 203-209.

4. Baziramakenga, R. and G.D. Leroux. 1994. Critical period of quackgrass (Elytrigia repens) removal in potatoes (Solanum tuberosum). Weed Sci. 42(4): 528-533.

5. Everman, W.J., I.C. Burke, S.B. Clewis, W.E. Thomas and J.W. Wilcut. 2008. Critical period of grass vs. broadleaf weed interference in peanut. Weed Technol. 22: 68-73.

6. Friesen, G.H. 1978. Weed interference in pickling cucumbers (Cucumis sativus). Weed Sci. 26(6): 626-628.

7. Jensen, J.E., J.C. Streibig and C. Andreasen. 1997. Weed Science Compendium. The Royal Veterinary and Agricultural University, Department of Agricultural Sciences, Section of Weed Science. 433p.

8. Gamliel, A. and A.H.C. Van Bruggen. 2016. Maintaining soil health for crop production in organic greenhouses. Sci. Hort. 208: 120-130.

9. Knezevic, S.Z., S.P. Evans, E.E. Blankenship, R.C. Van Acker and J.L. Lindquist. 2002. Critical period for weed control: The concept and data analysis. Weed Sci. 50: 773-786.

10. Knezevic, S.Z., S.P. Evans and M. Mainz. 2003. Row spacing influences the critical timing for weed removal in soybean (Glycine max). Weed Technol. 17: 666-673.

11. Knezevic, S.Z. and A. Datta. 2015. The critical period for weed control: Revisiting data analysis. Weed Sci. 63(SP1): 188-202.

12. Kolbe, W. 1977. Long-term studies on relations between weed cover and yield increase with chemical weed control (1967-1976). Pflanzenschutz Nachrichten.

13. Kudsk, P. and S.K. Mathiassen. 2007. Analysis of adjuvant effects and their interactions with variable application parameters. Crop Protec. 26: 328-334.

14. Kudsk, P. 2008. Optimising herbicide dose: A straightforward approach to reduce the risk of side effects of herbicides. Environ. 28: 49-55.

15. Martin, S.G., R.C. Van Acker and L.F. Friesen. 2001. Critical period of weed control in spring canola. Weed Sci. 49: 326-333.

16. Liebman, M., C.L. Mohler and C.P. Staver. 2001. Ecological Management of Agricultural Weeds. Cambridge University Press.

17. Naylor, R.E. (Ed.). 2008. Weed Management Handbook. John Wiley and Sons.

18. Radosevich, S.R., J.S. Holt and C. Ghersa. 1997. Weed Ecology: Implications for Management. John Wiley and Sons.

19. Rao, V.S. 2000. Principles of Weed Science. CRC Press.

20. Singh, K.P. 1973. Effect of temperature and light on seed germination of two ecotypes of Portulaca oleracea L. New Phytol. 72(2): 289-295.

21. Staniforth, D.W. 1961. Responses of corn hybrids to yellow foxtail competition. Weeds 9(1): 132-136.

22. Swanton, C.J., J. O'Sullivan and D.E. Robinson. 2010. The critical weed-free period in carrot. Weed Sci. 58: 229233.

23. Tursun, N., B. Bukun, S.C. Karacan, M. Ngouajio and H. Mennan. 2007. Critical period for weed control in leek 
(Allium porrum L.). Hort Sci. 42: 106-109.

24. Vangessel, M.J. and K.A. Renner. 1990. Redroot pigweed (Amaranthus retroflexus) and barnyardgrass (Echinochloa crus-galli) interference in potatoes (Solanum tuberosum). Weed Sci. 38(4-5): 338-343.

25. Weaver, S.E. and C.S. Tan. 1983. Critical period of weed interference in transplanted tomatoes (Lycopersicon esculentum): Growth analysis. Weed Sci. 31(4): 476-481.

26. Zimdahl, R.L. 2018. Fundamentals of Weed Science. Fourth ed., Academic Press, San Diego, CA, USA.

27. https://www.syngentaflowers-us.com/file/4811/download. 2012. 


\title{
Determination of The Critical Period of Greenhouse-Cucumber (Cucumis Sativus L.) Weeds in Soil Greenhouse
}

\author{
H. Hammami ${ }^{1 *}$, L. Alimoradi ${ }^{2}$ and A. Sepehri ${ }^{2}$
}

(Received: 5 September 2018 ; Accepted : 29 July 2019)

\begin{abstract}
In order to determine the critical period for weed control of greenhouse cucumber, an experiment was conducted in 2012 in a soil greenhouse located $25 \mathrm{~km}$ from Mashhad, as a randomized complete blocks design with three replications. The experiment consisted of two treatment series of weed interference. The first series consisted of weedinterference periods (including 14, 28, 42, 56, 70 and 84 days after emergence and the entire growth period of greenhouse cucumber) and the second series consisted of weed-free periods (including 14, 28, 42, 56, 70 and 84 days after emergence and the whole period of greenhouse cucumber growth). Results of this study showed that red root pigweed, common purslane, black nightshade, dwarf mallowand and common lambsquarters were the weeds with the highest density and biomass. Increasing or decreasing the weed-interference and weed-free periods led to changes in density, biomass, relative density and relative biomass of these plants. If 10,5 , and $1 \%$ of greenhouse cucumber yield loss are acceptable, then weed control must be carried out from 23 to 77 days (54 days), 18 to 94 days (76 days), and 16 to 107 days (91 days) after the greenhouse cucumber emerges, respectively. In general, the results of this experiment demonstrated that weed control in greenhouse cucumber production is necessary to achieve optimal yield.
\end{abstract}

Keywords: Density, Biomass, Acceptable yield loss, Weed.

1. Dept. of Agron. and Plant Breed., Faculty of Agric., Univ. of Birjand, Birjand, Iran.

2. Dept. of Agron. and Plant Breed., Islamic Azad Univ., Mashhad Branch, Mashhad, Iran.

* Corresponding Author, Email: Hhammami@birjand.ac.ir 